University of Windsor

Scholarship at UWindsor

2013

\title{
Food web structure in oil sands reclaimed wetlands
}

\author{
K. E. Kovalenko \\ University of Windsor \\ Jan J.H. Ciborowski \\ University of Windsor \\ C. Daly \\ University of Windsor \\ D. G. Dixon \\ University of Windsor \\ A. J. Farwell \\ University of Windsor
}

See next page for additional authors

Follow this and additional works at: https://scholar.uwindsor.ca/biologypub

Part of the Biology Commons

\section{Recommended Citation}

Kovalenko, K. E.; Ciborowski, Jan J.H.; Daly, C.; Dixon, D. G.; Farwell, A. J.; Foote, A. L.; Frederick, K. R.; Costa, J. M.; Kennedy, K.; Liber, K.; and Roy, M. C., "Food web structure in oil sands reclaimed wetlands" (2013). Ecological Applications, 23, 5, 1048-1060.

https://scholar.uwindsor.ca/biologypub/1073

This Article is brought to you for free and open access by the Department of Biological Sciences at Scholarship at UWindsor. It has been accepted for inclusion in Biological Sciences Publications by an authorized administrator of Scholarship at UWindsor. For more information, please contact scholarship@uwindsor.ca. 
Authors

K. E. Kovalenko, Jan J.H. Ciborowski, C. Daly, D. G. Dixon, A. J. Farwell, A. L. Foote, K. R. Frederick, J. M. Costa, K. Kennedy, K. Liber, and M. C. Roy 


\title{
Food web structure in oil sands reclaimed wetlands
}

\author{
K. E. Kovalenko, ${ }^{1,7}$ J. J. H. Ciborowski,${ }^{1}$ C. Daly, ${ }^{2}$ D. G. Dixon, ${ }^{3}$ A. J. Farwell,${ }^{3}$ A. L. Foote, ${ }^{4}$ \\ K. R. Frederick, ${ }^{4}$ J. M. Gardner Costa, ${ }^{1}$ K. Kennedy, ${ }^{1}$ K. Liber,${ }^{5}$ M. C. Roy ${ }^{4}$ \\ C. A. Slama, ${ }^{1}$ and J. E. G. Smits ${ }^{6}$ \\ ${ }^{1}$ Biological Sciences, University of Windsor, 401 Sunset Avenue, Windsor, Ontario N9B 3P4 Canada \\ ${ }^{2}$ Suncor Energy Inc., Edmonton, Alberta T2P $3 E 3$ Canada \\ ${ }^{3}$ Department of Biology, University of Waterloo, Waterloo, Ontario N2L $3 G 1$ Canada \\ ${ }^{4}$ Department of Renewable Resources, University of Alberta, Edmonton, Alberta T6G $2 \mathrm{H1}$ Canada \\ ${ }^{5}$ Toxicology Centre, University of Saskatchewan, Saskatoon, Saskatchewan S7N 5 B3 Canada \\ ${ }^{6}$ Ecosystem and Public Health Department, University of Calgary, Calgary, Alberta T2N 4Z6 Canada
}

\begin{abstract}
Boreal wetlands play an important role in global carbon balance. However, their ecosystem function is threatened by direct anthropogenic disturbance and climate change. Oil sands surface mining in the boreal regions of Western Canada denudes tracts of land of organic materials, leaves large areas in need of reclamation, and generates considerable quantities of extraction process-affected materials. Knowledge and validation of reclamation techniques that lead to self-sustaining wetlands has lagged behind development of protocols for reclaiming terrestrial systems. It is important to know whether wetlands reclaimed with oil sands process materials can be restored to levels equivalent to their original ecosystem function. We approached this question by assessing carbon flows and food web structure in naturally formed and oil sands-affected wetlands constructed in 1970-2004 in the postmining landscape. We evaluated whether a prescribed reclamation strategy, involving organic matter amendment, accelerated reclaimed wetland development, leading to wetlands that were more similar to their natural marsh counterparts than wetlands that were not supplemented with organic matter. We measured compartment standing stocks for bacterioplankton, microbial biofilm, macrophytes, detritus, and zoobenthos; concentrations of dissolved organic carbon and residual naphthenic acids; and microbial production, gas fluxes, and aquatic-terrestrial exports (i.e., aquatic insect emergence). The total biomass of several biotic compartments differed significantly between oil sands and reference wetlands. Submerged macrophyte biomass, macroinvertebrate trophic diversity, and predator biomass and richness were lower in oil sands-affected wetlands than in reference wetlands. There was insufficient evidence to conclude that wetland age and wetland amendment with peat-mineral mix mitigate effects of oil sands waste materials on the fully aquatic biota. Although high variability was observed within most compartments, our data show that 20 -year-old wetlands containing oil sands material have not yet reached the same level of function as their reference counterparts.
\end{abstract}

Key words: carbon flows; ecosystem function; macroinvertebrates; naphthenic acids; oil sands; tar sands; wetland reclamation.

\section{INTRODUCTION}

Boreal ecosystems store one-third of the world's terrestrial carbon (IPCC 2007). Boreal wetlands play a particularly important role in providing several essential ecosystem services, including carbon storage, flood control, water filtering and purification, water retention, and biodiversity (Bradshaw 2009, Schindler and Lee 2009, Wieder et al. 2009, Rooney et al. 2012). Yet this ecosystem type is undergoing rapid change as a result of anthropogenic activities resulting in deforestation, fragmentation, and altered disturbance regimes (Bradshaw et al. 2009). In particular, several recent studies

Manuscript received 25 July 2012; revised 17 December 2012; accepted 18 December 2012; final version received 14 January 2013. Corresponding Editor: C. B. Craft.

${ }^{7}$ E-mail: katya@uwindsor.ca expressed concern about the effects of current management of boreal resources, including natural gas and oil sands mining, on the capacity of boreal wetlands to perform freshwater-related ecosystem services (Schindler and Lee 2009, Foote 2012, Rooney et al. 2012).

Surface oil sands mining can be especially disruptive to the provision of ecosystem services. The extraction of bitumen from mined oil sands, and the direct disturbance caused by land clearing and subsurface hydrological disruption, generate large quantities of processaffected materials inherent to resource-intensive extraction. The Clark Hot Water Process is used to separate bitumen from sand, whereby hot water, and occasionally $\mathrm{NaOH}$, is mixed with the oil sand ore, and floating bitumen is skimmed from the slurry surface (Schramm et al. 2000). The remaining tailings slurry contains residual bitumen, sand, clay, polycyclic aromatic hydrocarbons (PAHs) and oil sand process water enriched in 
naphthenic acids and salts. The residual oil sands process materials (tailings and water; OSPM) are stored in large tailing ponds, which in 2009 had a volume of approximately one billion $\left(10^{9}\right)$ cubic meters (Simieritsch et al. 2009, Gosselin et al. 2010). The prospect of continuing accumulation of OSPM led to trial development and evaluation of reclamation strategies that incorporate this material into wetland landscapes.

Most studies of the effects of anthropogenic stressors tend to focus on population and community-level metrics, likely because they are more easily manipulated and presumed to be more sensitive than ecosystem-scale processes (assumptions that are seldom tested). Such a research focus has resulted in a limited understanding of the development of functional characteristics of constructed wetlands in general (but see Cornell et al. 2007) and oil sands wetlands in particular. The spatial extent of oil sands mining calls for landscape reclamation on a scale greatly exceeding most other reclamation projects. It is thus essential to know whether reclaimed OSPM wetlands are being restored to equivalent levels of ecosystem function, e.g., supporting food web structure and carbon flows similar to those observed in freshwater constructed wetlands of equivalent age. Although it is known that OSPM wetlands are colonized by some aquatic invertebrate and aquatic plant species (BendellYoung 2000, Leonhardt 2003), little information is available to judge whether the ecosystem processes of OSPM wetlands are becoming more similar to wetlands constructed with uncontaminated water. To address this question, we compared OSPM wetlands, constructed with oil sands process materials such as partially consolidated tailings and/or tailings water, or created by the upwelling of mine tailings water that leaked through dikes and was captured in depressions adjacent to mine waste-containing tailings ponds, with reference, freshwater wetlands containing uncontaminated sediments and water derived from precipitation and surface runoff.

Peatlands, bogs, and fens, which were the dominant wetland classes in the predisturbance landscape, take hundreds to thousands of years to accumulate the thickness of organic material that defines them. There is interest in determining whether amending reclaimed wetlands with peat accelerates wetland development and increases the similarity between OSPM and reference wetlands. Several reclaimed wetlands were amended with peat-mineral mixture, containing peat and the underlying mineral soil layer salvaged from the land originally cleared for mining and either temporarily stockpiled or directly placed on the bottom of newly constructed wetlands (usually $30 \%$ peat to $70 \%$ mineral mixture [Erwin and Best 1985, Alberta Environment 2008]). To address the importance of peat in the development of OSPM wetlands, we contrasted peatmineral amended OSPM wetlands and high organicmatter (OM) reference wetlands with nonamended OSPM wetlands and low-OM reference wetlands.
Overall, our goals were to (1) characterize effects of OSPM on major food web compartments and carbon flows, (2) examine wetland age-related differences in trophic structure between OSPM and reference wetlands of comparable age, (3) assess whether a commonly used reclamation strategy, peat-mineral mixture amendment, accelerated wetland development and increased similarity of OSPM and reference wetlands, and finally, (4) identify major gaps in our understanding of the viability of reclamation with oil sands materials. We approached these questions by evaluating major biotic compartments, carbon stocks, and processes central to the establishment of fully functioning aquatic ecosystems. In particular, we sampled and compared over a four-year period the biomass of major food web components in multiple constructed and naturally formed wetlands ranging in age from 2 to 20 years. In doing so, we aimed to assess the effects of the presence of mine tailings materials, and to understand which of these effects may be mitigated with age and by the application of peatmineral substrate during the construction period.

\section{Materials And Methods}

We synthesized results of multiple recent projects conducted under the Carbon Dynamics, Food Web Structure and Reclamation Strategies in Athabasca Oil Sands Wetlands (CFRAW) collaborative research framework (Ciborowski et al. 2006), the purpose of which was to understand carbon dynamics in wetlands constructed with and without the use of OSPM (Whelly 1999, Ganshorn 2002, Leonhardt 2003, Cooper 2004, Daly 2007, Frederick 2008, Barr 2009, Gardner-Costa 2010, Slama 2010), with previously unpublished data on macroinvertebrate community composition and food web structure.

\section{Study sites}

Study wetlands (Appendix: Table A1) were located in northeastern Alberta, Canada, on Syncrude Canada Ltd. and Suncor Energy Inc. mine lease areas and in areas that have not yet been mined (located between $53^{\circ} 28^{\prime}$ and $57^{\circ} 10^{\prime} \mathrm{N}$ and $111^{\circ} 45^{\prime}$ and $112.58^{\prime} \mathrm{W}$ ). Wetlands were typically marshes consisting of an openwater area (mean $\sim 7200 \mathrm{~m}^{2}$ ) with depth of $\sim 0.5-0.7 \mathrm{~m}$, surrounded by zones of emergent and wet-meadow vegetation. Wetlands were operationally classified as newly formed ( $\leq 7$ years) vs. older $(8+$ years $)$ at the time of sampling based on the previous study, which demonstrated leveling off of the invertebrate richness accumulation curves in OSPM wetlands after 7-8 years (Appendix: Fig. A1; Leonhardt 2003).

Reference wetlands were intentionally constructed or formed opportunistically in the depressions in the postmining landscape. These wetlands contained freshwater from precipitation and runoff and postmining salvaged sand and clay materials not contaminated with tar sand or its byproducts. Reference wetlands were termed high $\mathrm{OM}$ if there was peat-mineral mix or 
TABLE 1. Size of major carbon compartments in oil sands process material (OSPM) wetlands and their age-matched ("young," "old") reference counterpart (mean $\pm \mathrm{SD})$.

\begin{tabular}{|c|c|c|c|c|c|c|}
\hline Carbon compartment & OSPM young & Ref. young & $\begin{array}{l}\text { OSPM/ } \\
\text { Ref. (\%) }\end{array}$ & OSPM old & Ref. old & $\begin{array}{l}\text { OSPM/ } \\
\text { Ref. (\%) }\end{array}$ \\
\hline $\begin{array}{l}\text { Submerged plant biomass (g dry } \\
\text { mass } / \mathrm{m}^{2} \text { ) }\end{array}$ & $1.7 \pm 1.7$ & $34.2 \pm 24.1$ & 5.0 & $11.5 \pm 10.4$ & $52.0 \pm 19.3$ & 22.2 \\
\hline $\begin{array}{l}\text { Emergent macrophytes (g dry } \\
\text { mass } / \mathrm{m}^{2} \text { ) }\end{array}$ & 103.9 & $270.2 \pm 231.4$ & 38.5 & $189.6 \pm 95.5$ & $239.0 \pm 137.5$ & 79.3 \\
\hline $\begin{array}{l}\text { WMZ/allochthonous biomass ( } \mathrm{g} \\
\text { dry mass } / \mathrm{m}^{2} \text { ) }\end{array}$ & 35.0 & $116.4 \pm 67.7$ & 30.1 & $131.5 \pm 138.9$ & $183.4 \pm 153.5$ & 71.7 \\
\hline $\begin{array}{l}\text { Benthos biomass (mg dry mass/ } \\
\text { sweep) }\end{array}$ & $49.9 \pm 63.0$ & $378.2 \pm 135.6$ & 13.2 & $216.0 \pm 169.1$ & 124.5 & 173.5 \\
\hline $\begin{array}{l}\text { Planktonic pred. biomass (mg dry } \\
\text { mass/sweep) }\end{array}$ & $0.2 \pm 0.3$ & $14.4 \pm 20.3$ & 1.7 & $1.7 \pm 1.4$ & 1.6 & 106.4 \\
\hline $\begin{array}{l}\text { Emergence of Chironomidae ( } \mu \mathrm{g} \\
\text { dry mass/trap) }\end{array}$ & $4.6 \pm 6.2$ & 1.9 & 248.8 & $6.5 \pm 3.9$ & $1.4 \pm 0.3$ & 475.6 \\
\hline Bacterial biomass $(\mu \mathrm{g} \mathrm{C} / \mathrm{L})$ & $2.5 \pm 0.5$ & $2.8 \pm 2.8$ & 87.1 & $5.3 \pm 0.4$ & $2.0 \pm 0.6$ & 272.1 \\
\hline $\begin{array}{l}\text { Bacterial production } \\
\qquad\left(\mu \mathrm{g} \mathrm{C} \cdot \mathrm{L}^{-1} \cdot \mathrm{h}^{-1}\right)\end{array}$ & $0.3 \pm 0.3$ & $1.5 \pm 0.8$ & 17.7 & 0.1 & $0.3 \pm 0.1$ & 45.2 \\
\hline Organic matter in detritus $(\%)$ & $11.1 \pm 8.8$ & $9.9 \pm 7.2$ & 111.8 & $13.9 \pm 0.4$ & $12.7 \pm 4.1$ & 109.4 \\
\hline $\operatorname{NPP}\left(g \cdot m^{-3} \cdot d^{-1}\right)$ & $11.1 \pm 0.8$ & $7.8 \pm 5.9$ & 142.1 & $4.6 \pm 1.2$ & $2.6 \pm 9.2$ & 173.9 \\
\hline $\mathrm{CH}_{4}\left(\mu \mathrm{g} \cdot \mathrm{m}^{-2} \cdot \mathrm{d}^{-1}\right)$ & $1.9 \pm 1$ & $55.6 \pm 51.4$ & 3.5 & $35.9 \pm 44.9$ & $54.4 \pm 50.2$ & 66.0 \\
\hline $\mathrm{CO}_{2}\left(\mu \mathrm{g} \cdot \mathrm{m}^{-2} \cdot \mathrm{d}^{-1}\right)$ & $30.9 \pm 11.8$ & $13.3 \pm 8.7$ & 233.3 & $11.3 \pm 0.5$ & $26.7 \pm 11.9$ & 42.2 \\
\hline Naphthenic acids $(\mathrm{mg} / \mathrm{L})$ & 26.0 & $1.3 \pm 0.1$ & 2080.0 & $28.2 \pm 3.8$ & $5.0 \pm 6.3$ & 564.0 \\
\hline DOC (mg/L) & $66.6 \pm 12.6$ & $27.7 \pm 6.7$ & 240.2 & $59.0 \pm 0.4$ & $31.4 \pm 14.1$ & 188.3 \\
\hline
\end{tabular}

Notes: Key to abbreviations: WMZ, wet-meadow zone; NPP, net primary production; DOC, dissolved organic carbon.

muskeg soil supplementation during their construction. Several of the reference wetlands were beaver-created wetlands surrounded by mining infrastructure, or wetlands that formed "naturally" in depressions created by mining infrastructure but not directly disturbed during the land-clearing process. Reference wetlands had low levels of naturally occurring naphthenic acids (Table 1). OSPM wetlands were constructed with clay or a combination of clay, sand, and composite tailings as their base and filled with process waters originating from tailings ponds.

\section{Macrophytes}

Emergent and wet-meadow zone aquatic plants were sampled during the period of peak standing crop (end of August) in 2008. Plant biomass in the wet-meadow zone was used as a surrogate for allochthonous organic matter. In each of the 12 OSPM and 17 constructed reference wetlands sampled, three transects radiating from the pond center outward through each of the two vegetation zones were randomly placed. A $1-\mathrm{m}^{2}$ plot was assessed at a randomly selected location in each of two zones of each transect. One-quarter of the vegetation found inside the $1-\mathrm{m}^{2}$ plot in the emergent and wetmeadow zones was clipped. Aboveground plant biomass was measured after drying samples at $70^{\circ} \mathrm{C}$ for 48 hours.

Submerged macrophyte biomass was sampled in 8 OSPM and 10 reference wetlands in August 2009 and 2010 (Slama 2010). In each wetland, vegetation was sampled from five randomly selected open-water locations, where no emergent vegetation was present, at a depth of $\sim 40-60 \mathrm{~cm}$. At each location, vegetation was removed from a $1-\mathrm{m}^{2}$ quadrat with a thatching rake and frozen until later analysis. In the laboratory, macrophyte samples were thawed at room temperature over 24 hours, then dried in a drying oven at $110^{\circ} \mathrm{C}$ to a constant mass.

\section{Macroinvertebrates}

Aquatic invertebrates were sampled in four OSPM and three reference wetlands. Samples were collected with a sweep net, with similar sampling effort across all wetlands, at one-week intervals in July 2003 and preserved in Kahle's solution. Prior to sieving, flotation techniques were employed to separate organic matter from the inorganic fraction (Ciborowski 1991). The organic matter was then poured through a nested series of standard sieves $(4000,1000,500 \mu \mathrm{m})$. Invertebrates were removed and identified to genus or family (Clifford 1991, Merritt and Cummins 1996), photographed using a SPOT Insight digital camera (Spot Imaging Solutions, Sterling Heights, Michigan, USA), measured to the nearest $0.1 \mathrm{~mm}$ using ImageTool 3.0 software (University of Texas Health Science Center at San Antonio), and converted to biomass using published allometric coefficients (Benke et al. 1999). Due to high time-series variability and possible mass emergence, initial biomass in several wetlands was greater than biomass in the later sampling periods. Therefore, production could not be calculated. More detailed analysis (predator richness, total biomass, benthic and planktonic predator biomass) was performed on the invertebrate compartment as it represented the highest consistently available trophic level in those wetlands, which was assumed capable of integrating information from the lower trophic levels. 
Biomass of emerging aquatic insects was estimated using floating hoop traps. The floating hoops were $30 \mathrm{~cm}$ in diameter and made from $1.25 \mathrm{~cm}$ internal diameter plastic polyvinyl chloride pipe and acetate sheets, which were secured to the sediment with $45-\mathrm{cm}$ long bamboo stakes (Swisterski et al. 2005). Five floating hoops were randomly deployed in June 2009 in the emergent vegetation zone of nine wetlands: five reference and four OSPM wetlands. The surface of the water was cleared of any floating debris using a small aquarium net and hoops were left in the wetlands for 24 hours. Nymphal and pupal exuviae floating on the surface of the water were removed from within the area circumscribed by the hoop using a fine-mesh aquarium net. Exuviae were preserved in $70 \%$ ethanol, then counted, digitally photographed, and the length was digitally measured and converted to biomass using allometric equations (Benke et al. 1999).

\section{Microbial biomass and production}

Microbial biomass and production were determined in five reference and four OSPM wetlands. Bacterioplankton was filtered from 20-L water samples collected $10-15 \mathrm{~cm}$ below the surface. Secondary production was determined from ${ }^{3} \mathrm{H}$ leucine incorporation rates (modified from Kirchman and Ducklow 1993; see Daly 2007 for details on leucine saturation). Bacterial abundance was determined by labeling with DAPI stain and counting cells at $670 \times$ magnification using epifluorescence microscopy (Daly 2007). Bacterial biomass was estimated using a conversion factor of $20 \mathrm{fg} \mathrm{C} /$ cell (Lee and Fuhrman 1987).

Biofilm biomass was estimated by measuring chlorophyll $a$ (chl $a)$ concentrations. Biofilm was collected from acetate sheets immersed in two OSPM, two constructed reference, and two natural reference wetlands for a period of six weeks (Frederick 2008). Primary production was estimated from diel changes in dissolved oxygen concentration measured using in situ Hach MS5 multiprobes (Hach Hydromet, Loveland, Colorado, USA), which were deployed for 3-4 day intervals in 13 wetlands during late June until early September 2006. Organic carbon content of detritus was estimated by loss on ignition (details in Gardner-Costa 2010). Sediment samples were air-dried for 48 hours, followed by oven drying at $105^{\circ} \mathrm{C}$ for 24 hours. After measuring the dry mass, samples were ground with a mortar and pestle, incinerated at $550^{\circ} \mathrm{C}$ to constant mass, cooled in a desiccation chamber, and reweighed. Water samples for dissolved organic carbon analysis were collected in June, July, and August 2006. Samples were filtered through a $0.45 \mu \mathrm{m} \times 45 \mathrm{~mm}$ glass fiber filter and stored at $4^{\circ} \mathrm{C}$. Analysis was conducted at the University of Ottawa using high-temperature persulfate wet-oxidation (TICTOC Analyzer Model 1010, OI Analytical, College Station, Texas, USA; see Videla 2007 for further details). Water chemistry data (routine parameters, elemental chemistry, and naphthenic acid concentra- tions) were provided by Syncrude Canada, Ltd. (Edmonton, Alberta, Canada; M. MacKinnon, personal communication).

\section{Data analyses}

Normality and homoscedasticity of the data were tested using Shapiro-Wilk and the $F$ test for the equality of variances, respectively. Emergent and wet-meadow zone macrophyte biomass, $\mathrm{CH}_{4}$, and bacterial production data satisfied these assumptions after log transformation, and were analyzed using two-way ANOVAs based on age and organic matter amendment. Significant departures from normality and homoscedasticity, which could not be mitigated by data transformations, were observed for naphthenic acid concentrations, planktonic predator biomass, and emergent insect biomass data. Therefore, these three data sets were analyzed using nonparametric Mann-Whitney tests. The distribution of remaining data sets (submerged plant biomass, benthic invertebrate biomass, predator richness, bacterial biomass, OM in detritus, net primary production [NPP], $\mathrm{CO}_{2}$, and dissolved organic carbon [DOC]) did not depart from parametric assumptions; these data sets were also analyzed using two-way ANOVAs. Bonferroni corrections were used for withindata-set $P$ values (age and peat effect comparisons), but not for $P$ value adjustments across different data sets, because they represented independent experiments. All analyses were performed in PAST (Hammer et al. 2001) and $\mathrm{R}$ (version 2.12.2; R Development Core Team 2011).

Schematic flow charts were constructed for comparing OSPM and reference wetlands by expressing mean values (biomass, production, or concentration means) for each compartment and available flow in the OSPM wetlands as a percentage of a corresponding compartment of the reference wetlands of similar age and nutrient (organic matter [OM]) status. The direction of change across matched compartments between OSPM and reference wetlands was compared using paired sample $t$ tests.

\section{Stable isotopes}

Additional measures of food web structure were derived from stable isotope data (Elshayeb 2006). Carbon isotope ratios stay relatively constant (experiences minor fractionation within the food web) and can be used to track basal resources, whereas the ${ }^{15} \mathrm{~N} /{ }^{14} \mathrm{~N}$ ratios increase due to isotope fractionation and can thus be used to deduce information about an organism's trophic level (Fry 1991). Since isotope samples were collected as a part of a different study (Elshayeb 2006), which did not include OSPM wetlands of varying age and nutrient status, it was possible to compare OSPM and reference wetlands, but not to consider the effects of age class and peat amendment. Invertebrate samples were collected in July and early September 2003 and processed according to established protocols (see El- 
shayeb 2006 for details). Quantitative descriptions of food web structure (e.g., the extent of trophic diversity) can be derived by considering the total area occupied by species in the $\delta^{13} \mathrm{C}-\delta^{15} \mathrm{~N}$ isotope niche space (Layman et al. 2007a). Trophic diversity of invertebrate consumers was estimated from the convex hull area in a $\delta^{13} \mathrm{C}-\delta^{15} \mathrm{~N}$ biplot space using the PAST statistical package (Hammer et al. 2001) and compared between the OSPM vs. reference wetland classes using a $t$ test. Due to conspicuous differences in community structure between July and September collections, isotopic niche width was analyzed separately for summer (July) and fall (September). Stoichiometry (carbon-to-nitrogen ratio) of the main basal sources and bacterial consumers was analyzed to examine potential nutrient limitations (Elser et al. 2000).

\section{RESUlTS}

Most biotic compartments tended to be smaller in OSPM wetlands when compared to reference wetlands, in particular in young OSPM wetlands (Fig. 1a, onetailed paired comparison $t$ test for direction of change across compartments, $P=0.035$; Table 1); however, only some of those differences were significant in compartment-specific comparisons. Submerged and emergent macrophyte biomass in young OSPM wetlands was only $4 \%$ and $39 \%$ of that in the reference wetlands of equivalent age. OSPM had a significant effect on submergent macrophytes $(P<0.001$, see Appendix: Table A2 for detailed ANOVA tables), but not on the emergent macrophytes or wet-meadow zone plants $(P>0.05)$. Planktonic microbial production was similarly lower in OSPM wetlands than in reference wetlands $(P=0.046)$. Standing stocks of benthic macroinvertebrates in younger OSPM wetlands were only $13 \%$ of the biomass of those in similar-aged wetlands constructed with uncontaminated water, and overall OSPM wetland invertebrate biomass was only one-third of that in the reference wetlands, although this difference was not statistically significant due to high variability $(\mathrm{OSPM}, P=0.104, \mathrm{OSPM} \times$ age interaction, $P=0.071$; Fig. 2a).

Differences in compartment sizes between OSPM and reference wetlands tended to decline with age; however, this effect was not significant (OSPM $\times$ age interaction and age effect, $P>0.05$ for all compartments). Older OSPM wetlands tended to be more similar to the reference wetlands in biomass of benthic macroinvertebrates, planktonic predators, wet-meadow zone and emergent macrophytes, and microbial compartments, although submerged macrophyte biomass and microbial production values were still substantially lower than their reference wetland counterpart. In particular, submerged macrophytes in OSPM wetlands were only $22 \%$ of the biomass found in the reference wetlands. As an overall trend, compartments in the older OSPM wetlands were no longer consistently different from the reference wetlands (Fig. 1b, one-tailed paired sample $t$ test, $P>0.05$; Table 2).

Naphthenic acid concentrations in OSPM wetlands were seven times greater than those in the reference wetlands (Mann-Whitney test, $P=0.014$ ), and did not significantly decline with age $(P>0.05)$. The water concentration of dissolved organic carbon (DOC) was consistently greater in OSPM wetlands $(P=0.0004$, age effect and age $\times$ OSPM interaction, $P>0.05$ ). Organic matter content in detritus and biofilm biomass were similar between OSPM and reference wetlands regardless of age $(P>0.05)$. Methane fluxes were highly variable and did not differ consistently with regard to the presence of OSPM (Fig. 1, Table 1; $P>0.05$ for main effects and interactions: Appendix: Table A2). Carbon dioxide release was affected by OSPM as a function of age (OSPM $\times$ age interaction, $P=0.039)$. Net primary production measurements were unaffected by any of the factors $(P>0.05)$, and may not have been representative due to late-season decomposition and chemical oxygen demand.

More detailed analysis of the invertebrate compartment revealed that biomass of benthic invertebrate predators was significantly lower in young OSPM wetlands (only $2 \%$ of that of the reference wetlands; OSPM $\times$ age, $P=0.031$, OSPM effect, $P=0.042$ ). Furthermore, predator richness was also lower in young wetlands constructed with OSPM (OSPM $\times$ age, $P=$ 0.042 , OSPM effect, $P=0.033$, Fig. 2b). Mean biomass of emerging Chironomidae was not significantly affected by OSPM treatment (Fig. 2c; Mann-Whitney test, $P>$ 0.05; Export in Fig. 1a, b), but tended to be greater and more variable in OSPM wetlands.

Peat-mineral mix supplementation did not have significant effects on any of the compartments $(P>$ 0.05; Table 2; Appendix: Fig. A2, Table A2). In peatsupplemented OSPM wetlands, microbial biomass was three times greater than in high-OM reference wetlands, but production was approximately four times lower. Macroinvertebrate biomass in peat-supplemented OSPM wetlands was $79 \%$ of that in high-OM reference wetlands, whereas biomass in no-peat OSPM wetlands was only $12 \%$ of that in low-OM reference wetlands. Submerged macrophyte biomass was greatly reduced in peat-supplemented OSPM wetlands (4\% of submerged plant biomass in high-OM reference wetlands), whereas in no-peat OSPM wetlands submerged plant biomass was $28 \%$ of that in its counterpart low-OM reference wetlands; however, these effects were negligible in comparison to the effect of OSPM per se (peat effect and peat $\times$ OSPM interaction, $P>0.05$, whereas OSPM effect, $P<0.001$ ).

Isotopic niche width of macroinvertebrate consumers was $50 \%$ lower in OSPM wetlands than in reference wetlands in the summer (one-tailed $t$ test, $P=0.045$; Fig. 2d), whereas differences were not significant in the fall $(P$ $>0.05)$. There were no OSPM-related differences in trophic position of most common invertebrate groups $(P$ 

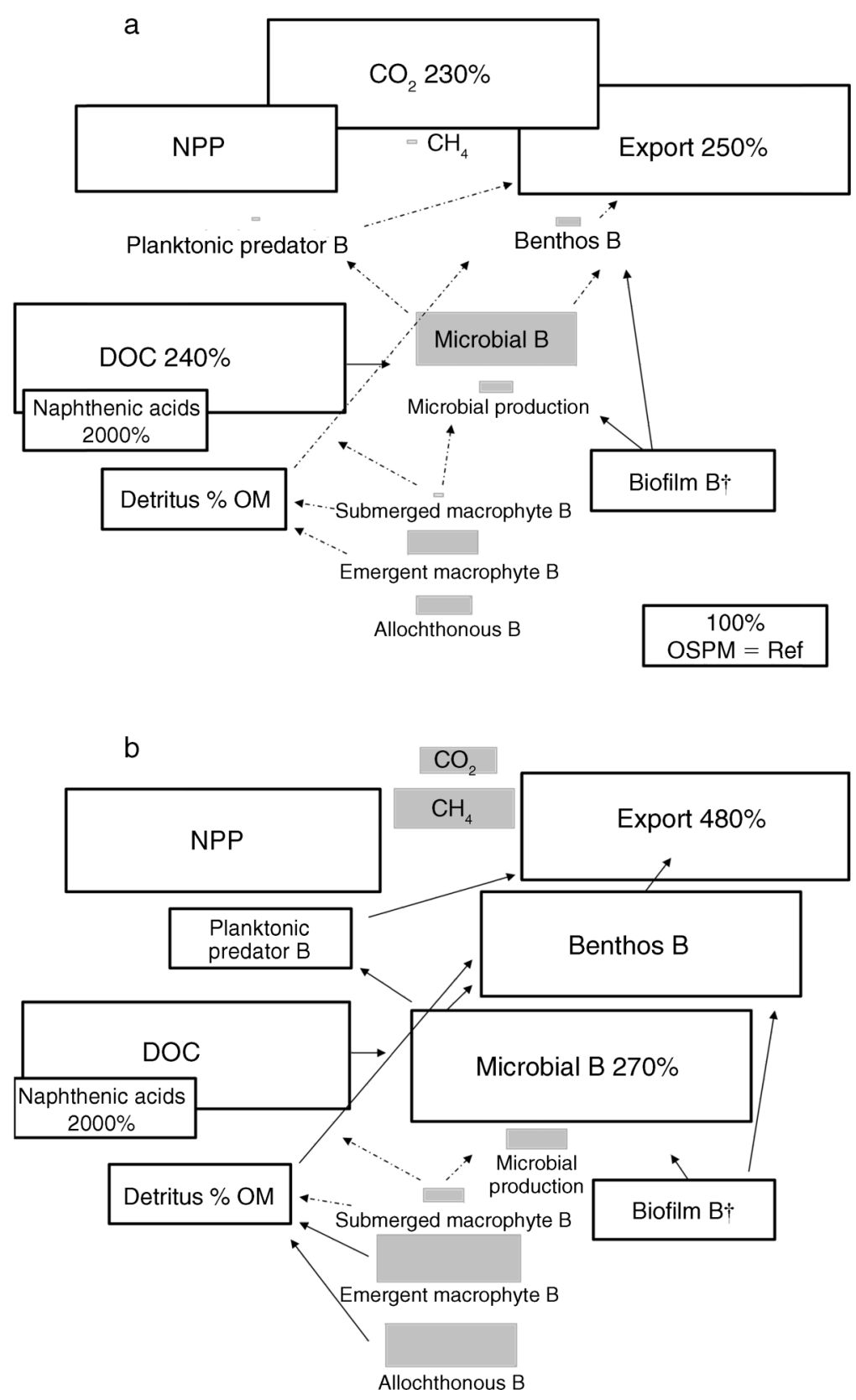

FIG. 1. Major carbon compartments in (a) young, and (b) older age classes of oil sands process materials (OSPM) wetlands expressed as a percentage of the corresponding compartments in reference wetlands of the similar age class. The size and shading of each box corresponds to the relative difference in each OSPM compartment relative to its reference counterpart. Similar or larger is represented by a white box of defined size; lower or smaller is represented by a gray-shaded box. For example, OSPM benthos biomass compartment, which is $13 \%$ of the reference compartment, is represented by a gray-shaded box $13 \%$ of the size of a reference box $[100 \%$, in the lower right corner of panel (a)]. Differences that were too large to display on the scale of the chart are indicated by percentages in the corresponding boxes. Arrows represent hypothetical flows among compartments, based on compartment size, with dashed arrows indicating decreased flows compared to reference. Key to abbreviations: B, biomass; DOC, dissolved organic carbon; NPP, net primary production; P, production; OM, organic matter.

$\uparrow$ OSPM-to-reference comparison only.

$>0.05)$. Stoichiometric analysis indicated that epiphytic bacteria in OSPM wetlands have $\sim 30 \%$ greater $\mathrm{C}: \mathrm{N}$ ratios, i.e., $\mathrm{N}$ deficiency $(P=0.004)$, whereas no significant OSPM-related differences were observed in
C:N ratios of algae and seston $(P>0.05$; Appendix: Fig. A3). Peat-mineral supplementation significantly reduced $\mathrm{C}: \mathrm{N}$ ratios of algae and seston $(P=0.04$ and 0.03 , respectively), but had no effect on bacteria $(P>0.05)$. 

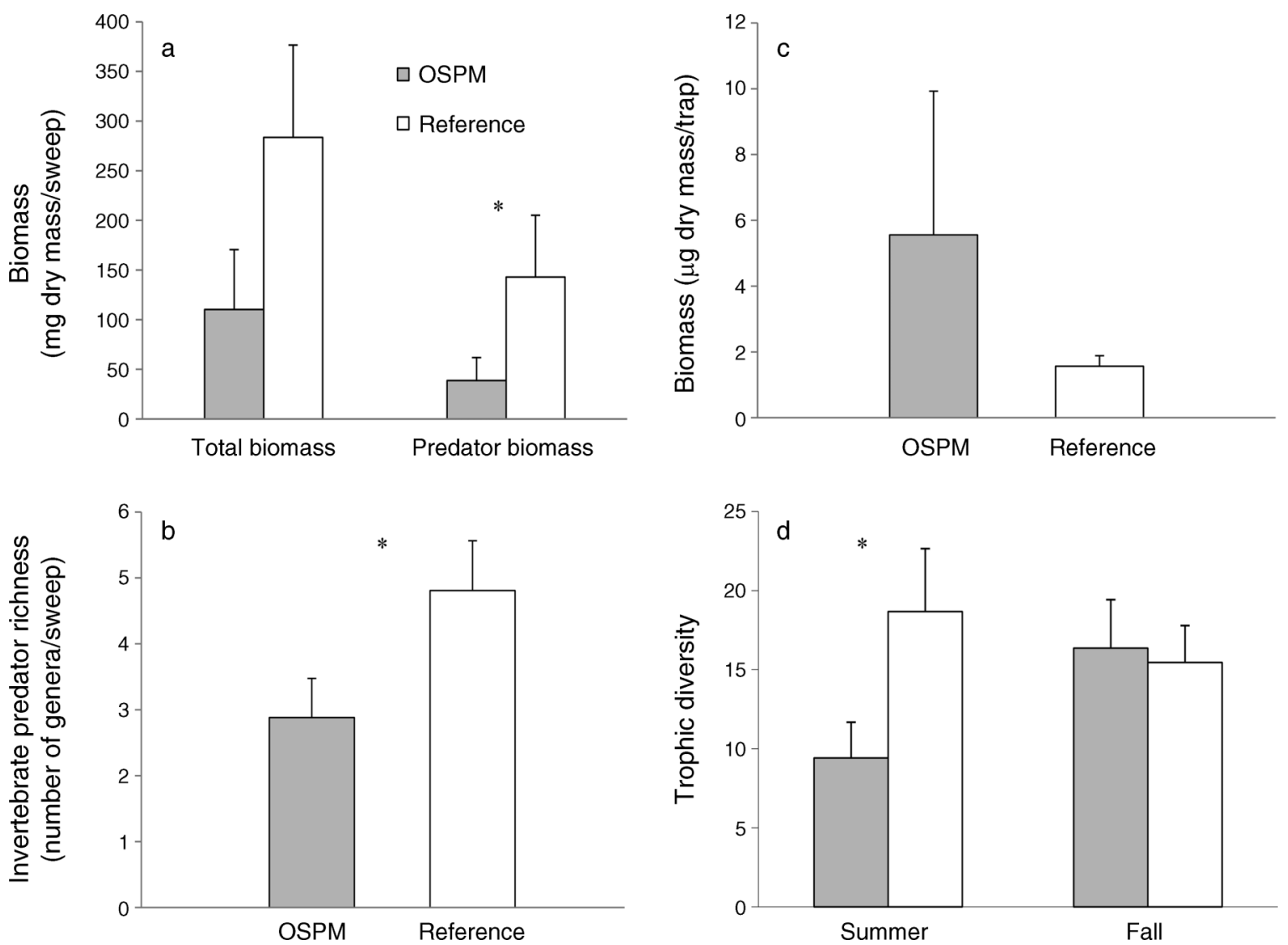

FIG. 2. Comparison of wetlands constructed with oil sands process materials (OSPM) and wetlands constructed with uncontaminated water and sediment (reference). (a) Total invertebrate biomass and benthic invertebrate predator biomass $(n=4-5$, $P=0.105$ for total invertebrate biomass and $P=0.042$ for predator biomass); (b) invertebrate predator richness $(n=4-5, P=$ $0.033)$; (c) biomass of emergent insects in summer and fall $(n=4-5, P=0.336)$; (d) trophic diversity in the summer and at the end of the growing season in the fall (mean convex hull area of isotopic biplot space; $n=4, P=0.045$ for summer, $P=0.82$ for fall). Values are means + SE. Significant differences $(P<0.05)$ are indicated with an asterisk $(*)$.

\section{DisCUSSION}

OSPM wetlands have lower macrophyte biomass, microbial biomass, trophic diversity, and invertebrate richness, and higher concentrations of naphthenic acids than wetlands constructed with uncontaminated water and sediments from the local landscape. Older OSPM wetlands tended to be more similar to the reference wetlands of equivalent age in terms of biomass of major biotic compartments (benthic and planktonic invertebrates, emergent macrophytes); however, the effect of age was not statistically significant, and several important differences remained. Initial discussion is directed at the role of OSPM-specific stressors potentially responsible for the observed differences in the biotic compartments, followed by compartment-specific discussion.

\section{Effects of oil sands stressors}

Several chemical constituents could be responsible for the observed toxicity of oil sands process water (OSPW), including naphthenic acids, salts, PAHs, trace metals and phenols (MacKinnon and Boerger 1986, Putta- swamy et al. 2010). Concentrations of several inorganic compounds, in particular, $\mathrm{Al}, \mathrm{As}, \mathrm{Cd}, \mathrm{Mo}$, and $\mathrm{Se}$ exceed the Canadian Water Quality Guidelines ${ }^{8}$ for the protection of aquatic life in freshwater and are of concern in terms of future toxicity to wetlands flora and fauna of the reclaimed sites (Whelly 1999). Initial detoxification of OSPW in shallow aerated pits leads to reduction in ammonia, oil, and cyanide (MacKinnon and Boerger 1986). Survival of rainbow trout (Oncorhynchus mykiss) and Daphnia magna improved after OSPW was stored in open pits for 12 months (96-hour static bioassays [MacKinnon and Boerger 1986]), although it took eight years to reduce subacute toxicity to D. magna (Nix and Martin 1992). Similarly, asymptotic levels of benthic invertebrate community family richness in OSPM and reference were observed in wetlands older than seven years (Leonhardt 2003).

Residual toxicity of OSPM is commonly attributed to naphthenic acids (MacKinnon and Boerger 1991, Her-

\footnotetext{
8 http://st-ts.ccme.ca/
} 
TABLE 2. Size of major carbon compartments in OSPM and reference wetlands, with and without organic matter ("peat") supplementation (mean $\pm \mathrm{SD}$ ).

\begin{tabular}{|c|c|c|c|c|c|c|}
\hline Carbon compartment & OSPM no peat & Ref. no peat & $\begin{array}{l}\text { OSPM/ } \\
\text { Ref. (\%) }\end{array}$ & OSPM peat & Ref. peat & $\begin{array}{l}\text { OSPM/ } \\
\text { Ref. (\%) }\end{array}$ \\
\hline $\begin{array}{l}\text { Submerged plant biomass (g dry } \\
\text { mass } / \mathrm{m}^{2} \text { ) }\end{array}$ & $13.4 \pm 10.2$ & $48.1 \pm 19.4$ & 27.9 & $1.9 \pm 2.8$ & $48.9 \pm 22.4$ & 3.8 \\
\hline $\begin{array}{l}\text { Emergent macrophytes (g dry } \\
\text { mass } / \mathrm{m}^{2} \text { ) }\end{array}$ & $183.8 \pm 98.8$ & $230.8 \pm 152.2$ & 79.6 & 167.3 & $303.0 \pm 233.2$ & 55.2 \\
\hline $\begin{array}{l}\text { WMZ/allochthonous biomass ( } \mathrm{g} \\
\text { dry mass } / \mathrm{m}^{2} \text { ) }\end{array}$ & $121.1 \pm 141.6$ & $144.7 \pm 90.9$ & 83.7 & 149.6 & $130.6 \pm 26.6$ & 114.5 \\
\hline $\begin{array}{l}\text { Benthos biomass (mg dry mass/ } \\
\text { sweep) }\end{array}$ & $36.0 \pm 52.4$ & $299.3 \pm 247.1$ & 12.0 & $223.8 \pm 158.0$ & 282.3 & 79.3 \\
\hline $\begin{array}{l}\text { Planktonic pred. biomass (mg dry } \\
\text { mass/sweep) }\end{array}$ & $1.0 \pm 1.5$ & $15.2 \pm 19.2$ & 6.3 & $0.6 \pm 0.1$ & 0.0 & na \\
\hline $\begin{array}{l}\text { Emergence of Chironomidae ( } \mu \mathrm{g} \\
\text { dry mass/trap) }\end{array}$ & $4.7 \pm 6.4$ & $1.5 \pm 0.3$ & 315.0 & $6.4 \pm 3.7$ & $1.5 \pm 0.5$ & 432.7 \\
\hline Bacterial biomass $(\mu \mathrm{g} \mathrm{C} / \mathrm{L})$ & $3.9 \pm 1.6$ & $4.2 \pm 2.6$ & 92.6 & $3.9 \pm 2.5$ & $1.3 \pm 0.2$ & 293.5 \\
\hline $\begin{array}{l}\text { Bacterial production } \\
\quad\left(\mu \mathrm{g} \mathrm{C} \cdot \mathrm{L}^{-1} \cdot \mathrm{h}^{-1}\right)\end{array}$ & $0.1 \pm 0.1$ & $0.6 \pm 0.3$ & 11.6 & $0.3 \pm 0.2$ & $1.2 \pm 1.1$ & 26.1 \\
\hline Organic matter in detritus (\%) & $12.1 \pm 6.4$ & $6.5 \pm 2.2$ & 187.9 & 13.6 & $15.0 \pm 0.3$ & 90.7 \\
\hline $\operatorname{NPP}\left(g \cdot m^{-3} \cdot d^{-1}\right)$ & $8.0 \pm 3.7$ & $-0.1 \pm 5.3$ & na & $7.7 \pm 5.6$ & $10.6 \pm 2.0$ & 72.8 \\
\hline $\mathrm{CH}_{4}\left(\mu \mathrm{g} \cdot \mathrm{m}^{-2} \cdot \mathrm{d}^{-1}\right)$ & $35.2 \pm 46$ & $42.4 \pm 35.9$ & 82.9 & $2.7 \pm 2.1$ & $67.6 \pm 58.3$ & 3.9 \\
\hline $\mathrm{CO}_{2}\left(\mu \mathrm{g} \cdot \mathrm{m}^{-2} \cdot \mathrm{d}^{-1}\right)$ & $25.1 \pm 20.1$ & $15.3 \pm 9.6$ & 164.2 & $17.1 \pm 7.8$ & $24.7 \pm 13.9$ & 69.4 \\
\hline Naphthenic acids (mg/L) & $25.8 \pm 0.4$ & 2.0 & 1287.5 & $28.5 \pm 3.5$ & $4.1 \pm 5.8$ & 693.9 \\
\hline DOC (mg/L) & $61.6 \pm 10.8$ & $23.4 \pm 4.5$ & 263.1 & $66.5 \pm 11.0$ & $35.7 \pm 11.5$ & 186.5 \\
\hline
\end{tabular}

Notes: Key to abbreviations: WMZ, wet-meadow zone; NPP, net primary production; DOC, dissolved organic carbon; na, no comparison was possible.

man et al. 1994, Lai et al. 1996, Toor et al. 2013). However, despite common references to naphthenic acid biodegradation, there was inconsistent evidence for biodegradation in situ. In particular, naphthenic acid profiles in older OSPM wetlands did not differ from those in the active settling basins (Han et al. 2009 [characterized using FTIR and HPLC]), although some dissipation has been noted in plant systems (Armstrong et al. 2009) and microcosm experiments (Toor et al. 2013). Several studies have showed that some fractions of oil sands-derived naphthenic acids are highly recalcitrant in comparison to commercially available naphthenic acids (Lai et al. 1996, Del Rio et al. 2006, Videla et al. 2009, Toor et al. 2013). Indirect evidence from isotope fractionation studies indicates that incorporation of OSPM-derived naphthenic acids is different from uptake routes observed in the laboratory with commercially available naphthenic acids, and only a minor fraction of OSPM-derived naphthenic acids is microbially metabolized (Videla et al. 2009). Further indirect evidence of limited degradation comes from observations of the persistence of naphthenic acids in OSPM wetlands that received only a single input of fresh tailings material at the time of their construction (Han et al. 2009).

Another ubiquitous stressor in OSPM wetlands is elevated salinity (reflected in conductivity of up to 3000 $\mu \mathrm{S} / \mathrm{cm}$ ), deriving from dissolution of ancient marine shale deposits during mining and disturbance of parent soils. Depending on the specifics of the extraction process, conductivity may be further elevated by the addition of sodium hydroxide, a caustic surfactant, during oil sands extraction and the subsequent use of coagulants (e.g., sulfuric acid, lime, gypsum, alum) to speed up flocculation of tailings (MacKinnon et al. 2001, Matthews et al. 2002). Biological effects ascribed to salinity could be mediated through disrupted balance among major ions (in particular mono- and divalent cations) and the elevated concentration of specific ions, rather than increased conductivity (total ionic content) per se. Salinity has negative effects on macroinvertebrate survival (e.g., Evans and Frick 2002, Hassell et al. 2006, Silver et al. 2009), alters community composition (Cuffney et al. 2010), and causes changes in food web structure (Van Meter et al. 2011). Macrophyte biomass can also be reduced by salinity (e.g., Twilley and Barko 1990, Merino et al. 2010), although levels at which these effects were reported generally exceeded those reported in the present study. Therefore, negative effects were speculated to result from ionic imbalance rather than merely from elevated salt concentrations (Rooney and Bayley 2011). Effects of salts could be additive to those of naphthenic acids (endpoint: phytoplankton community structure [Hayes 2005]); the addition of salts $(1 \mathrm{~g} / \mathrm{L})$ slightly increased larval mortality of fathead minnows exposed to naphthenic acids, but this effect depended on water hardness (A. J. Farwell, V. Nero, M. Mackinnon, and D. G. Dixon, unpublished manuscript). Furthermore, salinity stress may be exacerbated by water evaporation from wetlands during dry periods, which commonly occur during the summer in this region.

Population-level effects of these stressors propagate throughout the food web, leading to lower invertebrate and macrophyte biomasses observed in the OSPM wetlands. Furthermore, individual effects of toxicants can be exacerbated by the presence of other stressors (Lemly 1993, Gentes et al. 2006). The latter study, plus that of Harms et al. (2010), demonstrated that during 
ideal weather conditions, reclaimed wetlands can support healthy populations of aerially insectivorous birds, and survival of OSPM-exposed Tree Swallows (Tachycineta bicolor) is similar to that in reference wetlands, although growth may be affected. However, during a nesting season subject to harsher weather (cold with greater spring precipitation, limiting aerial insect activity and hence adult foraging success), Tree Swallow nestling survival in OSPM wetlands was markedly lower than in their reference counterparts (Gentes et al. 2006). Such nonlinearity is also possible at the ecosystem level, and could be partially responsible for the high variability observed in the present study.

\section{Macrophytes}

Submerged macrophyte biomass was consistently lower in OSPM wetlands than in their counterpart reference wetlands. Biomass of emergent and wetmeadow zone plants in older OSPM wetlands approached more closely (although nonsignificantly) that in the reference wetlands; however, many of the plants in OSPM wetlands were nonnative and, for the wetmeadow zone, primarily nonobligate wetland plants, e.g., Sonchus spp., Melilotus spp., Lotus corniculatus L. (M. C. Roy, personal communication). Another study demonstrated that submerged macrophyte assemblages in OSPM wetlands were different from those observed in natural oligosaline reference wetlands, possibly due to ionic imbalance in the former (Rooney and Bayley 2011), such as a prevalence of sulfate and sodium ions as opposed to divalent cations. This indicates that OSPM wetlands seem to be functionally different in this respect from both freshwater and oligosaline natural wetlands. Also, recent work has shown that emergent plants (Typha sp.) in OSPM wetlands had lower growth rates compared to those in wetlands constructed with nonOSPM water and sediments, leading to lower stand-level carbon assimilation (Mollard et al. 2012), which, in combination with lower macrophyte standing stocks, supports the present findings that use of OSPM in reclamation may be suboptimal. Aquatic plants are an essential component of aquatic ecosystems because they increase structural complexity of the underwater environment and support high diversity and biomass of periphyton and phytophilous invertebrates (e.g., Diehl and Kornijów 1997, Wetzel 2001). Submerged aquatic plants also play a critical role in terms of major wetland processes such as primary production, wave attenuation, sediment stabilization and oxygenation, and carbon sequestration (e.g., Carpenter and Lodge 1986, Barko and James 1997). Therefore, significant effects of OSPM on this compartment are likely to have cascading effects on the entire wetland ecosystem.

\section{Macroconsumers}

Although it was not possible to fully describe ecosystem topology and derive second-order measures of carbon flow (e.g., Baird et al. 1991), due to incomplete and temporally heterogeneous flow data (different compartments not sampled simultaneously), several significant trends could be observed from the available information. As the highest trophic level in these fishless wetlands, macroinvertebrates deserve special attention as integrators of energy flows from the preceding trophic levels. Wetlands with OSPM tended to have lower mean invertebrate biomass than reference wetlands. The range of variability in invertebrate abundance of OSPM wetlands overlapped with the lower range of the reference wetlands, indicating that the potential for development of invertebrate biomass comparable to reference sites exists, but it is not realized in most OSPM wetlands. Young OSPM wetlands were not capable of supporting benthic predator biomass to the same extent as reference wetlands. Furthermore, the lower richness of macroinvertebrate predators in OSPM wetlands is likely to result in reduced diversity of energy flows and an overall topological structure that could be less resilient to perturbations (Vinebrooke et al. 2003, Dunne et al. 2005). In addition to direct effects of OSPM, macroinvertebrates could be further limited by low macrophyte cover and biomass, because aquatic plants have positive effects on the abundance of most invertebrate taxa (e.g., Cyr and Downing 1988, Barr 2009). In contrast, emerging insect biomass was not significantly different between reference and oil-sandsaffected wetlands, due to a predominance of emerging chironomids, which are abundant in OSPM wetlands (Bendell-Young 2000, Leonhardt 2003, Kennedy 2012).

\section{Microbial biomass and production}

Microbial production was lower in OSPM wetlands than in reference wetlands, which was previously shown to correlate with increased salinity (Daly 2007). Young OSPM wetlands tended to have lower planktonic microbial biomass than reference wetlands, but this relationship was reversed in the older oil sands wetlands although microbial production remained low. Microbial production: biomass ratios were consistently higher in the reference wetlands, primarily due to greater production. Although higher P:B ratios are expected in young wetlands and are a possible indication of ecosystem immaturity (Odum 1969), in our study this trend may be indicative of different types of bacterial communities in OSPM wetlands (e.g., Hadwin et al. 2006) and the overall stress to the system. Similarly, in some marine upwelling systems, high P:B ratios were linked to high temporal heterogeneity of nutrient inputs (Baird et al. 1991).

\section{Insights from stable isotope ratios and stoichiometry}

Lower isotopic niche width was observed in OSPM wetlands in the summer. This could be caused by a low diversity of basal resources, as was previously shown for fragmented ecosystems (Layman et al. 2007b). However, in the autumn, the difference between OSPM and reference wetlands observed in the summer was no 
longer significant, likely reflecting community homogenization and a decrease in diversity with decreasing temperature. This observation differs from previously reported food web area analyses (Elshayeb 2006, Elshayeb et al. 2009), possibly because the latter compared three groups of sites with low, medium, and high naphthenic acid concentrations, and used a different method to quantify food web area. The greater $\mathrm{C}: \mathrm{N}$ ratios observed in OSPM wetlands relative to reference wetlands may be indicative of nitrogen limitation, possibly due to the presence of greater concentrations of recalcitrant organic carbon resulting from higher concentrations of hydrocarbons and lower macrophyte primary production.

It was impossible to determine whether OSPMderived carbon contributed to aquatic food webs, because $\delta^{13} \mathrm{C}$ values of emergent macrophytes and bitumen overlapped (based on data in Daly [2007]) and $\delta^{15} \mathrm{~N}$ values were very variable, likely a result of $\mathrm{NH}_{4}{ }^{+}$enrichment (Farwell et al. 2009), and could not be used to narrow down the sources. However, we speculate that a significant contribution of OSPM carbon is unlikely due to the highly refractory nature of OSPM-derived organic compounds ( $\mathrm{C}: \mathrm{N}$ ratios of $\sim 110: 1$ ).

\section{Effects of peat-mineral mix supplementation}

Peat amendment did not have a significant effect on the performance of reclaimed OSPM wetlands, although previous studies demonstrated that it can have positive effects on emergent plant diversity and abundance (Cooper 2004). Effects of peat addition can be multidirectional, reflecting complex interaction of water quality changes, alteration of substrate structural complexity, and addition of a potential nutrient subsidy for heterotrophic metabolism. Direct effects on water quality are manifested by lower dissolved oxygen levels due to organic matter oxidation and lower $\mathrm{pH}$ resulting from leaching of humic substances. Peat provides a resource base for heterotrophic production in systems where phytoplankton production is insufficient to sustain autotrophic food webs (Steinberg 2003). However, after initial consumption of easily metabolizable compounds, the remaining organic matter consists of a higher proportion of material recalcitrant to microbial degradation (Wetzel 2001). Humic substances in high concentrations can inhibit phytoplankton production and aquatic plant colonization and growth (Steinberg 2003). Macroinvertebrates are usually negatively affected by humic acids (cf. Steinberg 2003), through direct toxicity as well as by reducing the abundance of macrophytes. However, in many systems, a significant proportion of benthic production is supported by allochthonous organic matter (e.g., Smock and Roeding 1986) containing lower concentrations of humic acids. Indirect effects of peat amendment may be more complex. For example, metal and organic contaminant bioavailability and toxicity are reduced in the presence of humic compounds and with greater DOC concentrations in general (Welsh et al. 1996, Doig and Liber 2006), although bioavailability of other contaminants, including naphtha compounds, may increase (reviewed in Haitzer et al. 1998).

Based on the available data, it was not clear whether peat-mineral mix supplementation could expedite colonization and autotrophic production of OSPM wetlands. It is necessary to directly compare the role of in situ primary production and organic matter derived from peat-mineral amendments in the metabolism of constructed wetlands. One possible approach is to study ${ }^{14} \mathrm{C}$ concentrations, which will be lower in peat deposits before the atomic bomb than in more recently formed deposits (Hedges et al. 1986, Stern et al. 2007), and could therefore discriminate peat-derived carbon, because wetlands in this area were estimated to be at least 1890 years old (Trites and Bayley 2009). Alternatively, in situ labeling and compartment modeling could be used to resolve the relative importance of the various carbon sources (Oakes et al. 2010).

\section{Conclusions}

We conclude that OSPM wetlands are not functionally similar to the reference wetlands constructed without the use of OSPM over the time span considered. There is insufficient evidence to judge whether peatmineral amendments can mitigate the effects of OSPM. Organic matter accumulation remains an important unknown in assessment of the reclamation potential of oil sands wetlands, with implications for landscape-scale carbon storage and sequestration potential and for ensuring appropriate proportional representation of wetlands in the reclaimed landscape. Until functional similarity of OSPM wetlands can be demonstrated, prognosis of wetland reclamation will have a high degree of uncertainty in terms of ensuring long-term viability of reclaimed wetlands and maintenance of carbon balance and biodiversity.

\section{ACKNOWLEDGMENTS}

This research was supported by grants from the Natural Sciences and Engineering Research Council of Canada, Syncrude Canada Ltd., Suncor Energy Inc., Canadian Natural Resources Ltd., Albian Sands Energy (Shell Canada), Total E\&P Canada Ltd., Imperial Oil, and the Canadian Water Network to J. Ciborowski and co-PIs (D. G. Dixon, A. L. Foote, K. Liber, and J. E. G. Smits). We thank M. Elshayeb for providing stable isotope data and $\mathrm{C}$. Leonhardt for permission to reproduce Appendix A: Fig. A1. We gratefully acknowledge the field and lab assistance of many students and technicians, including J. Hwang, M. Dobrin, L. Barr, K. Ganshorn, B. Hersikorn, M. Jajo, H. Yosief, J. Martin, S. Nakhaie, K. Jurkowski, L. Pandit, J. Dowson, M. Chen, A. Nelson, R. Kavanagh, J. Hornung, L. Baker, A. Swisterski, M. Boenke, and A. Namayandeh. We also thank C. Beierling, T. Van Meer, C. Campbell, L. Cyprien, J. Clark, N. Jelfs, M. MacKinnon, M. Fung, C. Qualizza, N. Rutley, and C. Wytrykush for assistance on site at Syncrude Canada Ltd, and W. Tedder, B. Anderson, L. Pacquin, P. Marlowe for assistance on site at Suncor Energy Inc. C. Wytrykush provided invaluable help at every stage of this project, collected field data for the DO and macroinver- 
tebrate compartments, and commented on an earlier version of the manuscript. We thank two anonymous reviewers for helpful suggestions on how to improve the manuscript.

\section{Literature Cited}

Alberta Environment. 2008. Guideline for wetland establishment on reclaimed oil sands leases. Second edition. Prepared by M. L. Harris of Lorax Environmental for the Wetlands and Aquatics Subgroup of the Reclamation Working Group of the Cumulative Environmental Management Association, Fort McMurray, Alberta, Canada.

Armstrong, S. A., J. V. Headley, and J. J. Germida. 2009. Differences in phytotoxicity and dissipation between ionized and nonionized oil sands naphthenic acids in wetland plants. Environmental Toxicology and Chemistry 28:2167-2174.

Baird, D., J. M. McGlade, and R. E. Ulanowicz. 1991. The comparative ecology of six marine ecosystems. Philosophical Transactions of the Royal Society B 333:15-29.

Barko, J. W., and W. F. James. 1997. Effects of submerged aquatic macrophytes on nutrient dynamics, sedimentation, and resuspension. Pages 197-214 in E. Jeppesen, M. Søndergaard, and K. Christoffersen, editors. The structuring role of submerged macrophytes in lakes. Springer, New York, New York, USA.

Barr, L. 2009. Influences of tailings water, sediments, macrophytes and detritus on zoobenthic community development in constructed wetlands-results of a reciprocal transplant study. Thesis. University of Windsor, Windsor, Ontario, Canada.

Bendell-Young, L. I., K. E. Bennett, A. Crowe, C. J. Kennedy, A. R. Kermode, M. M. Moore, A. L. Plant, and A. Wood. 2000. Ecological characteristics of wetlands receiving an industrial effluent. Ecological Applications 10:310-322.

Benke, A. C., A. D. Huryn, L. A. Smock, and J. B. Wallace. 1999. Length-mass relationships for freshwater macroinvertebrates with particular reference to Southeastern United States. Journal of the North American Benthological Society 18:308-343.

Bradshaw, C. J. A., I. G. Warkentin, and N. S. Sodhi. 2009. Urgent preservation of boreal carbon stocks and biodiversity. Trends in Ecology and Evolution 24:541-548.

Carpenter, S. R., and D. M. Lodge. 1986. Effects of submersed macrophytes on ecosystem processes. Aquatic Botany 26:341-370.

Ciborowski, J. J. H. 1991. Estimating processing time of stream benthic samples. Hydrobiologia 222:101-107.

Ciborowski, J. J. H., D. G. Dixon, L. Foote, K. Liber, and J. E. Smits. 2006. Carbon dynamics, food web structure and reclamation strategies in Athabasca oil sands wetlands. Canadian Technical Report on Fisheries and Aquatic Sciences 2746:16.

Clifford, H. F. 1991. Aquatic invertebrates of Alberta. University of Alberta Press, Edmonton, Alberta, Canada.

Cooper, N. 2004. Vegetation community development of reclaimed oil sands wetlands. Thesis. University of Alberta, Edmonton, Alberta, Canada.

Cornell, J. A., C. B. Craft, and J. P. Megonigal. 2007. Ecosystem gas exchange across a created salt marsh chronosequence. Wetlands 27:240-250.

Cuffney, T. F., R. A. Brightbill, J. T. May, and I. R. Waite. 2010. Responses of benthic macroinvertebrates to environmental changes associated with urbanization in nine metropolitan areas. Ecological Applications 20:1384-1401.

Cyr, H., and J. A. Downing. 1988. Empirical relationships of phytomacrofaunal abundance to plant biomass and macrophyte bed characteristics. Canadian Journal of Fisheries and Aquatic Sciences 45:975-984.

Daly, C. 2007. Carbon sources, microbial community production, and respiration in constructed wetlands of the Alberta, Canada oil sands mining area. Thesis. University of Windsor, Windsor, Ontario, Canada.
Del Rio, L. F., A. K. M. Hadwin, L. J. Pinto, M. D. MacKinnon, and M. M. Moore. 2006. Degradation of naphthenic acids by sediment micro-organisms. Journal of Applied Microbiology 101:1049-1061.

Diehl, S., and R. Kornijów. 1997. Influence of submerged macrophytes on trophic interactions among fish and macroinvertebrates. Pages 24-46 in E. Jeppesen, M. Søndergaard, and $\mathrm{K}$. Christoffersen, editors. The structuring role of submerged macrophytes in lakes. Springer, New York, New York, USA.

Doig, L. E., and K. Liber. 2006. Influence of dissolved organic matter on nickel bioavailability and toxicity to Hyalella azteca in water-only exposures. Aquatic Toxicology 76:203216.

Dunne, J. A., U. Brose, R. J. Williams, and N. D. Martinez. 2005. Modeling food web dynamics: complexity-stability implications. Pages 117-129 in A. Belgrano, U. M. Scharler, J. Dunne, and R. E. Ulanowics, editors. Aquatic food webs: an ecosystem approach. Oxford University Press, New York, New York, USA.

Elser, J. J., et al. 2000. Nutritional constraints in terrestrial and freshwater food webs. Nature 408:578-580.

Elshayeb, M. 2006. Determining food web impacts on experimental aquatic systems from the disposal of oil sands process-affected waste materials. Thesis. University of Waterloo, Waterloo, Ontario, Canada.

Elshayeb, M., M. MacKinnan, D. G. Dixon, and M. Power. 2009. The use of carbon and nitrogen stable isotope analysis to characterize food web changes in aquatic systems for reclamation of oil sands process-affected materials. Water Quality Research Journal of Canada 44:313-322.

Erwin, K. L., and G. R. Best. 1985. Marsh community development in a central Florida phosphate surface-mined reclaimed wetland. Wetlands 5:155-166.

Evans, M., and C. Frick. 2002. The effects of road salts on aquatic ecosystems. NWRI Contribution Number 02-308 Environment Canada. National Water Research Institute, Burlington/Saskatoon, Canada.

Farwell, A. J., V. Nero, K. Ganshorn, C. Leonhardt, J. Ciborowski, M. MacKinnon, and D. G. Dixon. 2009. The use of stable isotopes $\left({ }^{13} \mathrm{C} /{ }^{12} \mathrm{C}\right.$ and $\left.{ }^{15} \mathrm{~N} /{ }^{14} \mathrm{~N}\right)$ to trace exposure to oil sands processed material in the Alberta oil sands region. Journal of Toxicology and Environmental Health (A) 72:385-396.

Farwell, A. J., V. Nero, M. Mackinnon, and D. G. Dixon. Effects of salinity and water hardness on the toxicity of naphthenic acids to larval fathead minnows. In preparation.

Foote, A. L. 2012. Threshold considerations and wetland reclamation in Alberta's mineable oil sands. Ecology and Society 17:35.

Frederick, K. R. 2008. Using biofilms and grazing midges (Diptera, Chironomidae) to determine productivity, nitrogen isotope baseline and enrichment in food webs among wetlands differing in anthropogenic stressors. Honours Thesis. University of Windsor, Windsor, Ontario, Canada.

Fry, B. 1991. Stable isotope diagrams of freshwater food webs. Ecology 72:2293-2297.

Ganshorn, K. D. 2002. Secondary production, trophic position, and potential for accumulation of polycyclic aromatic hydrocarbons in predatory Diptera in four wetlands in the Athabasca oil sands, Alberta, Canada. Thesis. University of Windsor, Windsor, Ontario, Canada.

Gardner-Costa, J. M. 2010. Spatial and temporal variation in sediment-associated microbial respiration in oil sands mineaffected wetlands of north-eastern Alberta, Canada. Thesis. University of Windsor, Windsor, Ontario, Canada.

Gentes, M. L., C. Waldner, Z. Papp, and J. E. G. Smits. 2006. Effects of oil sands tailings compounds and harsh weather on mortality rates, growth and detoxification efforts in nestling tree swallows (Tachycineta bicolor). Environmental Pollution 142:24-33. 
Gosselin, P., S. E. Hrudey, A. Naeth, A. Plourde, R. Therrien, G. vander Kraak, and Z. Xu. 2010. Environmental and health impacts of Canada's oil sands industry. Royal Society of Canada. http://www.rsc-src.ca/documents/ RSCreportcompletesecured9Mb_Mar28_11_00 0.pdf

Hadwin, A. K. M., L. F. Del Rio, L. J. Pinto, M. Painter, R. Routledge, and M. M. Moore. 2006. Microbial communities in wetlands of the Athabasca oil sands: genetic and metabolic characterization. FEMS Microbiology Ecology 55:68-78.

Haitzer, M., S. Höss, W. Traunspurger, and C. Steinberg. 1998. Effects of dissolved organic matter (DOM) on the bioconcentration of organic chemicals in aquatic organisms-a review. Chemosphere 37:1335-1362.

Hammer, Ø., D. A. T. Harper, and P. D. Ryan. 2001. PAST: Paleontgiolocal Statistics Software Package for Education and Data Analysis. Palaeontologia Electronica 4:9. http:// palaeo-electronica.org/2001_1/past/issue1_01.htm

Han, X., M. D. MacKinnon, and J. W. Martin. 2009. Estimating the in situ biodegradation of naphthenic acids in oil sands process waters by HPLC/HRMS. Chemosphere 76:63-70.

Harms, N. J., G. D. Fairhurst, G. R. Bortolotti, and J. E. G. Smits. 2010. Variation in immune function, body condition, and feather corticosterone in nestling Tree Swallows (Tachycineta bicolor) on reclaimed wetlands in the Athabasca oil sands, Alberta, Canada. Environmental Pollution 158:841848 .

Hassell, K. L., B. J. Kefford, and D. Nugegoda. 2006. Sublethal and chronic salinity tolerances of three freshwater insects: Cloeon sp. and Centroptilum sp. (Ephemeroptera: Baetidae) and Chironomus sp. (Diptera: Chironomidae). Journal of Experimental Biology 209:4024-4032.

Hayes, T. M. E. 2005. Examining the ecological effects of naphthenic acids and major ions on phytoplankton in the Athabasca Oil Sands Region. Dissertation. University of Waterloo, Waterloo, Ontario, Canada.

Hedges, J. I., J. R. Ertel, P. D. Quay, P. M. Grootes, J. E. Richey, A. H. Devol, G. W. Farwell, F. W. Schmidt, and E. Salati. 1986. Organic C-14 in the Amazon River system. Science 231:1129-1131.

Herman, D., P. Fedorak, M. MacKinnon, and J. Costerton. 1994. Biodegradation of naphthenic acids by microbial populations indigenous to oil sands tailings. Canadian Journal of Microbiology 40:467-477.

IPCC. 2007. Climate Change 2007: Synthesis Report. Contribution of Working Groups I, II and III to the Fourth Assessment Report of the Intergovernmental Panel on Climate Change 104. Intergovernmental Panel on Climate Change, Zurich, Switzerland.

Kennedy, K. 2012. Growth, survival, and community composition of Chironomidae (Diptera) larvae in selected Athabasca oil sands process-affected wetland waters of northeastern Alberta. Thesis. University of Windsor, Windsor, Ontario, Canada.

Kirchman, D. L., and H. W. Ducklow. 1993. Estimating conversion factors for thymidine and leucine methods for measuring bacterial production. Pages 513-518 in P. F. Kemp, B. F. Sherr, E. B. Sherr, and J. J. Cole, editors. Handbook of methods in aquatic ecology. Lewis, Chelsea, Michigan, USA.

Lai, J., L. Pinto, E. Kiehlmann, L. Bendell-Young, and M. Moore. 1996. Factors that affect the degradation of naphthenic acids in oil sands wastewater by indigenous microbial communities. Environmental Toxicology and Chemistry 159:1482-1491.

Layman, C. A., D. A. Arrington, C. G. Montaña, and D. M. Post. 2007a. Can stable isotope ratios provide for community-wide measures of trophic structure? Ecology 88:42-48.

Layman, C. A., J. P. Quattrochi, C. M. Peyer, and J. E. Allgeier. 2007b. Niche width collapse in a resilient top predator following ecosystem fragmentation. Ecology Letters 10:937-944.

Lee, S., and J. A. Fuhrman. 1987. Relationships between biovolume and biomass of naturally derived marine bacterioplankton. Applied and Environmental Microbiology 53(6):1298-1303.

Lemly, A. D. 1993. Metabolic stress during winter increases the toxicity of selenium to fish. Aquatic Toxicology 27:133-158.

Leonhardt, C. L. 2003. Zoobenthic succession in constructed wetlands of the Fort McMurray oil sands region: development of zoobenthic recovery. Thesis. University of Windsor, Windsor, Ontario, Canada.

MacKinnon, M., and H. Boerger. 1986. Description of two treatments for detoxifying oil sands tailings pond water. Water Pollution Research Journal of Canada 21:496-512.

MacKinnon, M., and H. Boerger. 1991. Assessment of a wet landscape option for disposal of fine tails sludge from oil sands processing. In Proceedings of the Petroleum Society of CIM and AOSTRA 1991 Technical Conference, Banff, Alberta, 21-24 April 1991. AOSTRA-CIM Paper Number 91-124. Alberta Oil Sands Technology and Research Authority (AOSTRA), Edmonton, Alberta, Canada.

MacKinnon, M. D., J. G. Matthews, W. H. Shaw, and R. G Cuddy. 2001. Water quality issues associated with composite tailings (CT) technology for managing oil sands tailings. International Journal of Surface Mining, Reclamation and Environment 15:235-256.

Matthews, J. G., W. H. Shaw, M. D. MacKinnon, and R. G. Cuddy. 2002. Development of composite tailings technology at Syncrude. International Journal of Surface Mining, Reclamation and Environment 16:24-39.

Merino, J. H., D. Huval, and A. J. Nyman. 2010. Implication of nutrient and salinity interaction on the productivity of Spartina patens. Wetlands Ecology and Management 18:111-117.

Merritt, R. W., and K. W. Cummins, editors. 1996. An introduction to the aquatic insects of North America. Third edition. Kendall-Hunt, Dubuque, Iowa, USA.

Mollard, F. P. O., M.-C. Roy, K. Frederick, and L. Foote. 2012. Growth of the dominant macrophyte Carex aquatilis is inhibited in oil sands affected wetlands in Northern Alberta, Canada. Ecological Engineering 38:11-19.

Nix, P., and R. Martin. 1992. Detoxification and reclamation of Suncor's oil sand tailings ponds. Environmental Toxicology and Water Quality 7:171-188.

Oakes, J. M., R. M. Connolly, and A. T. Revill. 2010. Isotope enrichment in mangrove forests separates microphytobenthos and detritus as carbon sources for animals. Limnology and Oceanography 55:393-402.

Odum, E. P. 1969. The strategy of ecosystem development. Science 164:262-270.

Puttaswamy, N., D. Turcotte, and K. Liber. 2010. Variation in toxicity response of Ceriodaphnia dubia to Athabasca oilsands coke leachates. Chemosphere 80:489-497.

R Development Core Team. 2011. R Foundation for Statistical Computing, Vienna, Austria.

Rooney, R. C., and S. E. Bayley. 2011. Setting reclamation targets and evaluating progress: submersed aquatic vegetation in natural and post-oil sands mining wetlands in Alberta, Canada. Ecological Engineering 37:569-579.

Rooney, R. C., S. E. Bayley, and D. W. Schindler. 2012. Oil sands mining and reclamation cause massive loss of peatland and stored carbon. Proceedings of the National Academy of Sciences USA 109:4933-4937.

Schindler, D. W. 2009. Lakes as sentinels and integrators for the effects of climate change on watersheds, airsheds, and landscapes. Limnology and Oceanography 54:2349-2358.

Schindler, D. W., and P. G. Lee. 2009. Comprehensive conservation planning to protect biodiversity and ecosystem services in Canadian boreal regions under a warming climate 
and increasing exploitation. Biological Conservation 143:1571-1586.

Schramm, L. L., E. N. Stasiuk, and M. MacKinnon. 2000. Surfactants in Athabasca oil sands slurry conditioning, flotation recovery, and tailings process. Pages 365-430 in L. L. Schramm, editor. Surfactants, fundamentals and applications in the petroleum industry. Cambridge University Press, Cambridge, UK.

Silver, P., S. M. Rupprecht, and M. F. Stauffer. 2009. Temperature-dependent effects of road deicing salt on chironomid larvae. Wetlands 29:942-951.

Simieritsch, T., J. Obad, and S. Dyer. 2009. Tailings plan review. Pembina Institute Publication, Calgary, Alberta, Canada.

Slama, C. A. 2010. Sediment oxygen demand and sediment nutrient content of reclaimed wetlands in the Oil Sands Region of north-eastern Alberta. Thesis. University of Windsor, Windsor, Ontario, Canada.

Smock, L. A., and C. E. Roeding. 1986. The trophic basis of production of the macroinvertebrate community of a southeastern U.S.A. blackwater stream. Holarctic Ecology 9:165-174.

Steinberg, C. E. W. 2003. Ecology of humic substances in freshwaters. Springer, Heidelberg, Germany.

Stern, J., Y. Wang, B. Gu, and J. Newman. 2007. Distribution and turnover of carbon in natural and constructed wetlands in the Florida Everglades. Applied Geochemistry 22:19361948.

Swisterski, A., J. J. H. Ciborowski, C. M. Wytrykush, and C. Beierling. 2005. A novel approach to assess chironomid (Diptera: Chironomidae) community composition in the Athabasca oil sands region. Canadian Technical Report of Fisheries and Aquatic Sciences 2617:43.

Toor, N. S., E. Franz, P. M. Fedorak, M. D. MacKinnon, and K. Liber. 2013. Evaluating the degradation and aquatic toxicity of naphthenic acids in Athabasca oil sands processaffected waters using simulated wetlands. Chemosphere 90:449-458.
Trites, M., and S. E. Bayley. 2009. Organic matter accumulation in western boreal saline wetlands: a comparison of undisturbed and oil sands wetlands. Ecological Engineering 35:1734-1742.

Twilley, R. R., and J. W. Barko. 1990. The growth of submersed macrophytes under experimental salinity and light conditions. Estuaries 13:311-321.

Van Meter, R. J., C. M. Swan, J. Leips, and J. W. Snodgrass. 2011. Road salt stress induces novel food web structure and interactions. Wetlands 31:843-851.

Videla, P. P. 2007. Examining oil sands dissolved carbon and microbial degradation using stable isotope analysis. Thesis. University of Waterloo, Waterloo, Ontario, Canada.

Videla, P., A. Farwell, B. Butler, and D. Dixon. 2009. Examining the microbial degradation of naphthenic acids using stable isotope analysis of carbon and nitrogen. Water, Air and Soil Pollution 197:107-199.

Vinebrooke, R. D., D. W. Schindler, D. L. Findlay, M. A. Turner, M. Paterson, and K. H. Mills. 2003. Trophic dependence of ecosystem resistance and species compensation in experimentally acidified lake $302 \mathrm{~S}$ (Canada). Ecosystems 6:101-113.

Welsh, P. G., J. L. Parrott, D. G. Dixon, P. V. Hodson, D. J. Spry, and G. Mierle. 1996. Estimating acute copper toxicity to larval fathead minnow (Pimephales promelas) in soft water from measurements of dissolved organic carbon, calcium and $\mathrm{pH}$. Canadian Journal of Fisheries and Aquatic Sciences 53:1263-1271.

Wetzel, R. G. 2001. Limnology: lake and river ecosystems. Third edition. Academic Press, San Diego, California, USA.

Whelly, M. P. 1999. Aquatic invertebrates in wetlands of the oil sands region of northeast Alberta, Canada, with emphasis on Chironomidae (Diptera). Thesis. University of Windsor, Windsor, Ontario, Canada.

Wieder, R. K., K. D. Scott, K. Kamminga, M. A. Vile, D. H. Vitt, T. Bone, B. Xu, B. W. Benscoter, and J. S. Bhatti. 2009. Postfire carbon balance in boreal bogs of Alberta, Canada. Global Change Biology 15:63-81.

\section{Supplemental Material}

\section{Appendix}

Tables presenting information about study wetlands and ANOVA results for the effects of OSPM and age/peat, and figures demonstrating separation of wetlands based on family richness of benthic invertebrates, effects of peat on major carbon compartments, and effects of OSPM on stoichiometric ratios of algae, bacteria, and seston (Ecological Archives A023-054-A1). 


\section{Ecological Archives A023-054-A1}

K. E. Kovalenko, J. J. H. Ciborowski, C. Daly, D. G. Dixon, A. J. Farwell, A. L. Foote, K. R. Frederick, J. M. Gardner Costa, K. Kennedy, K. Liber, M. C. Roy, C. A. Slama, and J. E. G. Smits. 2013. Food web structure in oil sands reclaimed wetlands. Ecological Applications 23:1048-1060. http://dx.doi.org/10.1890/12-1279.1

APPENDIX A. Tables presenting information about (Table A1) study wetlands and (Table A2) ANOVA results for the effects of OSPM and age/peat, and figures demonstrating (Fig. A1) separation of wetlands based on family richness of benthic invertebrates, (Fig. A2) effects of peat on major carbon compartments, and (Fig. A3) effects of OSPM on stoichiometric ratios of algae, bacteria, and seston.

TABLE A1. Information about study wetlands and sampling information (sampled for (1) submerged macrophytes; (2) DOC; (3) biofilm; (4) Naphthenic acids; (5) Bacterial biomass and production; (6) invertebrates; (7) aquatic-terrestiral flux/ invertebrate emergence; (8) detritus; (9) gas fluxes; (10) stable isotopes). MFT - mature fine tailings.

\begin{tabular}{|c|c|c|c|c|}
\hline Wetland class & Wetland name & Year created & $\begin{array}{c}\text { Organic } \\
\text { matter }\end{array}$ & \\
\hline OSPM & Test Pond 9 & 1992 & Low OM & Proce \\
\hline OSPM & Mike's Pond & 1997 & Low OM & \\
\hline OSPM & SWSS Berm & 1979 & Peat-mineral amended & \\
\hline OSPM & Seepage Control Pond & 1978 & Low OM & \\
\hline OSPM & Natural Wetland & 1987 & Peat-mineral amended & $\operatorname{Pr}$ \\
\hline OSPM & $4 \mathrm{~m} \mathrm{CT}$ & 1999 & Peat-mineral amended and non-amended & \\
\hline OSPM & Jan's Pond & 1999 & Low OM & \\
\hline OSPM & Demo Pond & 1993 & Low OM & \\
\hline OSPM & Test Pond 5 & 1989 & Low OM & \\
\hline OSPM & Test Pond 3 & 1989 & Low OM & \\
\hline
\end{tabular}




\begin{tabular}{|c|c|c|c|}
\hline OSPM & Test Pond 7 & 1989 & Low OM \\
\hline $\begin{array}{c}\text { Table A1 (cont-d) } \\
\text { Wetland class }\end{array}$ & Wetland name & Year created & $\begin{array}{l}\text { Organic } \\
\text { matter }\end{array}$ \\
\hline Reference & South Beaver & natural, unknown & Low OM \\
\hline Reference & South West Sands & natural, unknown & High OM \\
\hline Reference & Muskeg & natural, unknown & High OM \\
\hline Reference & High Sulphate & 1985 & High OM \\
\hline Reference & Golden Pond & 2001 & High OM \\
\hline Reference & Shallow Wetland & 1992 & Low OM \\
\hline Reference & Pond 5 & 2002 & Low OM \\
\hline Reference & Waste Area 11 & 1993 & Low OM \\
\hline Reference & Peat Pond & 2000 & High OM \\
\hline Reference & Bill's Lake & 1997 & Low OM \\
\hline Reference & CNRL & 2004 & Low OM \\
\hline Reference & North West Interception Ditch & 1970 & Low OM \\
\hline Reference & South Bison & natural, unknown & High OM \\
\hline Reference & Test Pond 1 & 1989 & Low OM \\
\hline
\end{tabular}
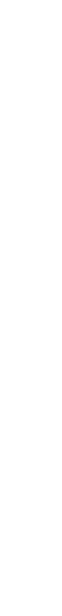


\begin{tabular}{|c|c|c|c|c} 
Reference & Barge Marsh & 1978 & Low OM & High OM \\
\hline Reference & Beaver Creek Reservoir & 1975 & & \\
\hline
\end{tabular}

TABLE A2. Two-way ANOVA tables for the effects of OSPM and age and OSPM and peat on major wetland compartments. Non-parametric equivalents (Mann-Whitney test) are presented for several compartments, which had unsatisfactory fit to ANOVA assumptions even after data transformation. Significant effects are highlighted in green. 


\section{AGE EFFECT}

\section{Microbial biomass}

\begin{tabular}{lrrrrr} 
& Sumsqrs & df & Meansqr & \multicolumn{2}{l}{$\mathrm{p}$} \\
OSPM effect & 4.405 & 1 & 4.405 & 1.35 & 0.2979 \\
Age effect & 2.02 & 1 & 2.02 & 0.62 & 0.4672 \\
Interaction & 7.607 & 1 & 7.607 & 2.33 & 0.1875 \\
Within & 16.33 & 5 & 3.266 & & \\
Total & 29.76 & 8 & & &
\end{tabular}

Microbial production (log)

\begin{tabular}{lrrrrr} 
& Sumsqrs & df & \multicolumn{1}{l}{ Meansqr } & \multicolumn{2}{l}{ F } \\
OSPM effect & 1.244 & 1 & 1.244 & 6.95 & 0.04617 \\
Age effect & 0.3605 & 1 & 0.3605 & 2.01 & 0.2151 \\
Interaction & 0.2926 & 1 & 0.2926 & 1.64 & 0.2572 \\
Within & 0.8949 & 5 & 0.179 & & \\
Total & 2.658 & 8 & & &
\end{tabular}

Submergent plant biomass

\begin{tabular}{lrrrrr} 
& Sumsqrs & df & Meansqr & \multicolumn{1}{l}{ F } & \multicolumn{1}{l}{$p$} \\
OSPM effect & 5692 & 1 & 5692 & 19.17 & 0.00063 \\
Age effect & 280.2 & 1 & 280.2 & 0.94 & 0.3478 \\
Interaction & 221.6 & 1 & 221.6 & 0.75 & 0.4022 \\
Within & 4156 & 14 & 296.9 & & \\
Total & $1.08 \mathrm{E}+04$ & 17 & & &
\end{tabular}

Wet meadow zone (log)

\begin{tabular}{lrrrrr} 
& Sumsqrs & df & Meansqr & \multicolumn{1}{l}{ F } & \multicolumn{1}{l}{ P } \\
OSPM effect & 0.08972 & 1 & 0.08972 & 0.64 & 0.4329 \\
Age effect & 0.2956 & 1 & 0.2956 & 2.10 & 0.1606 \\
Interaction & 0.06119 & 1 & 0.06119 & 0.43 & 0.5163 \\
Within & 3.384 & 24 & 0.141 & & \\
Total & 3.92 & 27 & & &
\end{tabular}

Emergent vegetation (log)

\begin{tabular}{lrrrrr} 
& \multicolumn{1}{c}{ Sumsqrs } & df & Meansqr & \multicolumn{1}{l}{ F } & \\
OSPM effect & 0.05313 & 1 & 0.05313 & 0.54 & 0.4699 \\
Age effect & 0.000803 & 1 & 0.0008 & 0.01 & 0.9288 \\
Interaction & 0.03642 & 1 & 0.03642 & 0.37 & 0.5489 \\
Within & 2.365 & 24 & 0.09854 & & \\
Total & 2.459 & 27 & & &
\end{tabular}

Microbial biomass

Sumsqrs

$\begin{array}{ll}\text { OSPM effect } & 4.405 \\ \text { Peat effect } & 6.528 \\ \text { Interaction } & 4.556 \\ \text { Within } & 15.35 \\ \text { Total } & 29.76\end{array}$

Microbial production Sumsqrs

$\begin{array}{lr}\text { OSPM effect } & 1.244 \\ \text { Peat effect } & 0.4498 \\ \text { Interaction } & 0.17 \\ \text { Within } & 0.9439 \\ \text { Total } & 2.658\end{array}$

Submergent plant biomass

\begin{tabular}{lr} 
& Sumsqrs \\
\hline OSPM effect & 6604 \\
\hline Peat effect & 25.32 \\
Interaction & 374.8 \\
Within & 3572 \\
Total & $1.04 \mathrm{E}+04$
\end{tabular}

Wet meadow zone (log) Sumsqrs

OSPM effect $\quad 0.2338$

Peat effect $\quad 0.02657$

Interaction $\quad 0.07944$

Within 2.018

Total 2.314

Emergent vegetation (log Sumsqrs

OSPM effect $\quad 0.06275$

Peat effect $\quad 0.03506$

Interaction $\quad 0.009009$

Within

2.338

Total

2.419 


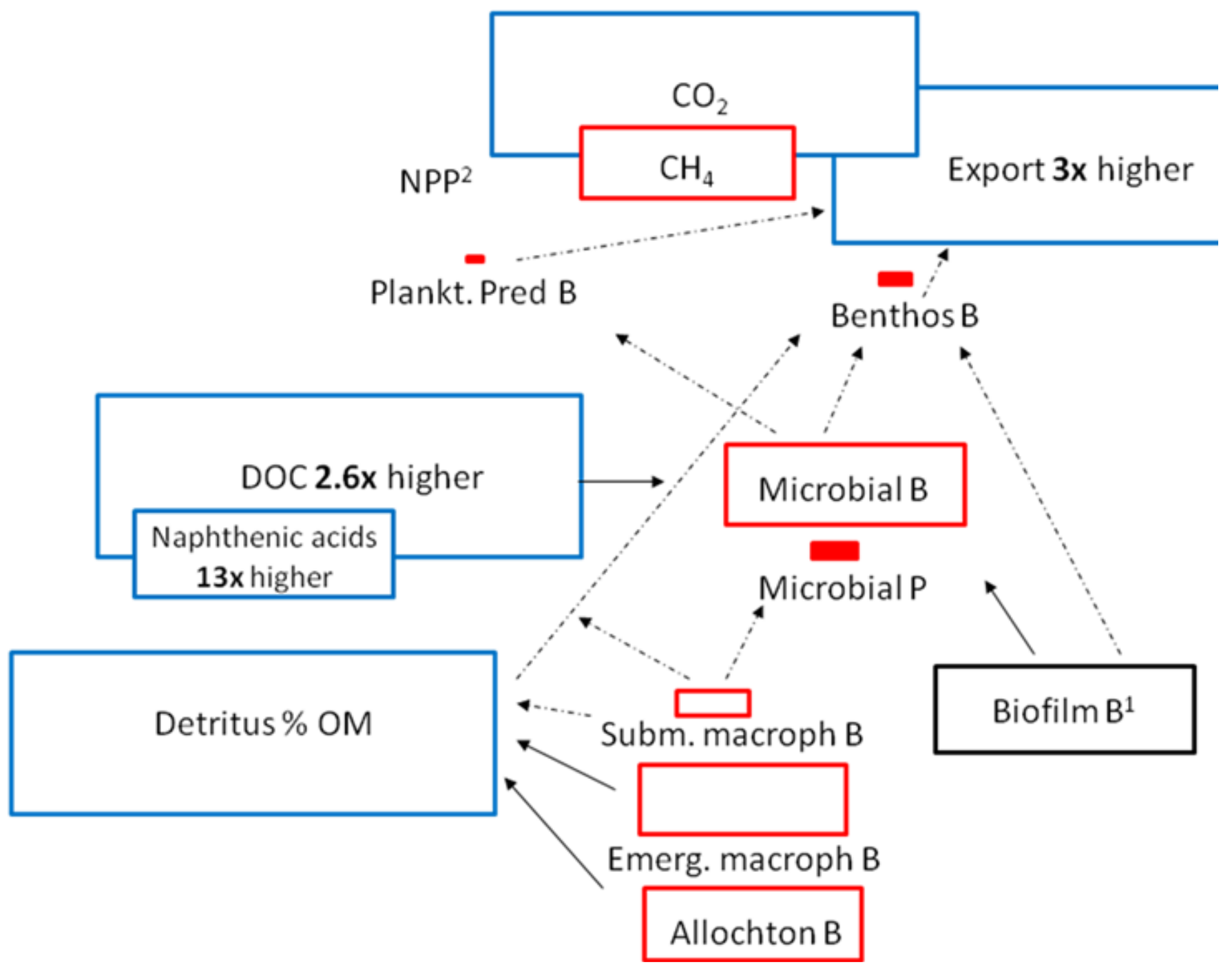

b)

Allochton B

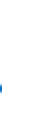

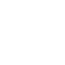




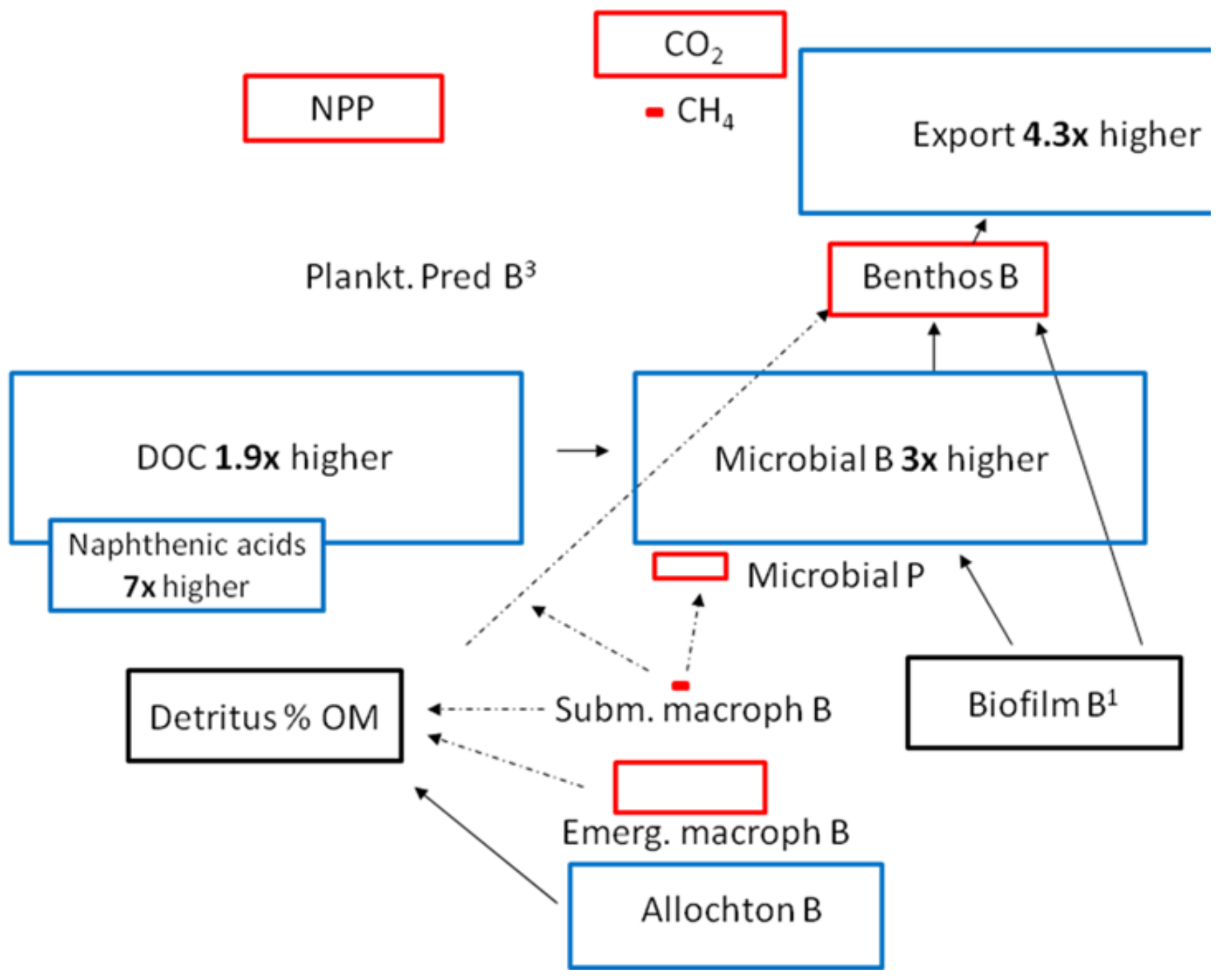

FIG. A2. Major carbon compartments in peat-unamended (a) and peat-amended (b) OSPM wetlands expressed as a
percentage of the corresponding compartments in reference wetlands of comparable organic matter content. The size

FIG. A2. Major carbon compartments in peat-unamended (a) and peat-amended (b) OSPM wetlands expressed as a
percentage of the corresponding compartments in reference wetlands of comparable organic matter content. The size and color of each box corresponds to the relative difference in each compartment (same as Fig. 1). 1 OSPM-toreference comparison only; 2 negative NPP in reference possibly due to macrophyte decomposition; 3 no planktonic predators in OM-supplemented reference wetlands; B - biomass, DOC - dissolved organic carbon, NPP -Net Primary

Export 4.3x higher

\title{
Detritus \% OM
}

Naphthenic acids

x higher

\section{Benthos B}

\section{Biofilm B ${ }^{1}$} Production, P-production.

\begin{abstract}
Production, $\mathrm{P}$ - production.
\end{abstract}




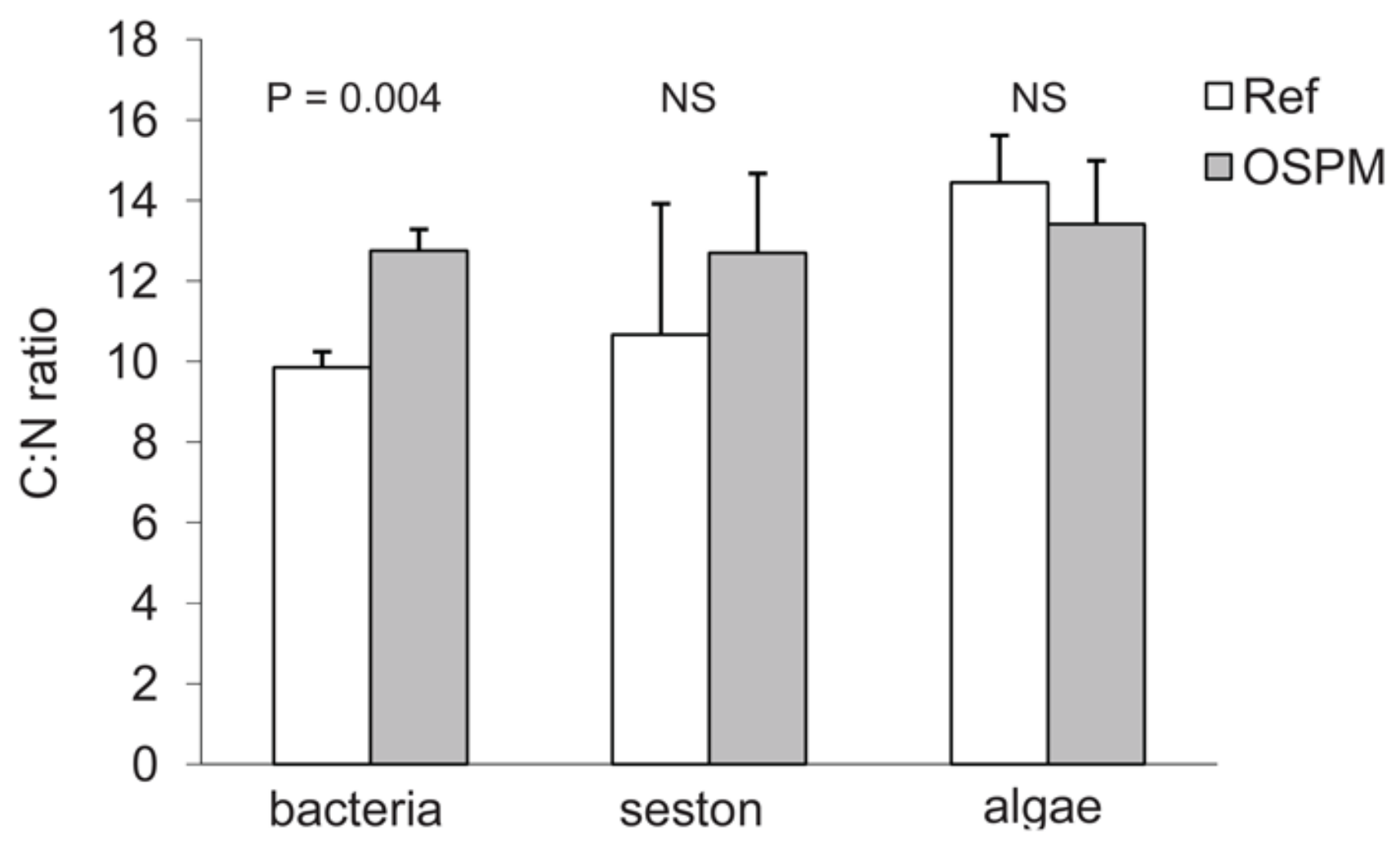

FIG. A3. Stoichiometric ratios of algae, bacteria, and seston from OSPM and reference wetlands (mean \pm SE).

\section{LITERATURE CITED}

Leonhardt, C. L. 2003. Zoobenthic succession in constructed wetlands of the Fort McMurray oil sands region: development of zoobenthic recovery. M.S. Thesis, University of Windsor, ON, Canada.

[Back to A023-054] 